\title{
Impact of wildfire smoke in Buenos Aires, Argentina, on ocular surface
}

\author{
Efeitos da fumaça de incêndios na superfície ocular em Buenos Aires, Argentina
}

Martin Berra ${ }^{1,2}$, Gustavo Galperín ${ }^{1,2}$, Laura Dawidowski $^{3}$, Julia Tau², Isabel Márquez ${ }^{4}$, Alejandro Berra 2,4

\begin{abstract}
Purpose: To evaluate the acute impact of the wildfire smoke episode in 2008 on the ocular surface of subjects living in the Metropolitan Area of Buenos Aires (MABA). Methods: A total of 86 subjects were evaluated: Group 1 comprised patients from a public ophthalmology hospital $(\mathrm{N}=35)$ and Group 2 comprised healthy volunteers $(\mathrm{N}=51)$. All subjects answered a questionnaire on ocular symptoms and underwent ophthalmologic examination [bulbar conjunctival hyperemia, corneal fluorescein staining, rose bengal vital staining, tear break-up time (TBUT), Schirmer I test, tear lysozyme, and impression cytology] during and after the acute episode. Concentrations of carbon monoxide $(\mathrm{CO})$, nitrogen dioxide $\left(\mathrm{NO}_{2}\right)$, and particulate matter (PM) were measured before, during, and after the acute episode. Results: Both groups showed a statically significant increase in ocular symptoms and bulbar conjunctival hyperemia and a statically significant decrease in tear break-up time during the acute episode. Group 1 showed more severe symptoms and a statistically significant increase in fluorescein and rose bengal staining intensities during the acute episode. We found a significant negative correlation between ocular symptoms and tear break-up time. During the episode, the levels of $\mathrm{CO}, \mathrm{NO}_{2}$, and particulate matter in MABA were four times higher than the usual average levels for the same period in 2007 and 2009.

Conclusions: Increased air pollution from the burning of biomass is associated with a decrease in the stability of the tear film (TBUT), generating areas of ocular surface exposure that may be the cause of the increased feeling of irritation. Group 1 was more affected by not having a healthy ocular surface, and thus consulted an ophthalmologist. Cytological changes in the conjunctiva were not observed, which could be due to the short duration of the episode.
\end{abstract}

Keywords: Urban fires; Conjunctiva/cytology; Cytodiagnosis; Air pollution; Tears/ physiology; Fluorescein/diagnostic use; Rose bengal/diagnostic use; Hyperemia; Argentina

\section{RESUMO}

Objetivo: Avaliar os efeitos agudos da fumaça do episódio de incêndio violento ocorrido em 2008, sobre a superfície ocular de sujeitos que vivem na Região Metropolitana de Buenos Aires (MABA).

Métodos: Um total de 86 indivíduos foram avaliados: Grupo 1: pacientes de um hospital público de oftalmologia ( $N=35)$ e Grupo 2: voluntários saudáveis $(N=51)$. Todos os participantes responderam a um questionário sobre os sintomas oculares e foram submetidos a exame oftalmológico (hiperemia conjuntival bulbar, teste de fluoresceína, corante rosa bengala, tempo de ruptura do filme lacrimal (TBUT), teste de Schirmer I, lisozima lacrimal e citologia de impressão) durante e após o episódio agudo. As concentrações de monóxido de carbono, dióxido de nitrogênio e partículas (PM) foram medidas antes, durante e após o episódio agudo.

Resultados: Ambos os grupos apresentaram aumento estatisticamente significativo dos sintomas oculares, hiperemia conjuntival bulbar, e diminuição estatisticamente significativa no tempo de ruptura do filme lacrimal durante o episódio agudo. Grupo 1 apresentou maior intensidade dos sintomas e aumento estatisticamente significativo no teste de fluoresceína e rosa bengala durante o episódio agudo. Encontramos uma correlação negativa significativa entre os sintomas oculares e tempo de ruptura do filme lacrimal. Durante o episódio agudo de 2008, os níveis de $\mathrm{CO}, \mathrm{NO}_{2}$ ePM na Região Metropolitana de Buenos Aires foram 4 vezes maiores do que os níveis médios habituais para o mesmo período de 2007 e 2009.

Conclusões: $O$ aumento da poluição do ar a partir da queima de biomassa está associado a uma diminuição da estabilidade do filme lacrimal (TBUT) gerando zonas da exposição da superfície ocular, que podem ser a causa do aumento da sensação de irritação. Grupo 1 foi mais afetado por não ter superfície ocular saudável e, portanto, consultaram um oftalmologista. Mudanças citológicas da conjuntiva não foram observadas e isso poderia ser devido à curta duração do episódio.

Descritores: Incêndios urbanos; Conjuntiva/citologia; Citodiagnóstico; Poluição do ar; Lágrimas/fisiologia; Fluoresceína/uso diagnóstico; Rosa bengala/uso diagnóstico; Hiperemia; Argentina

\section{INTRODUCTION}

The Metropolitan Area of Buenos Aires (MABA) is comprises Buenos Aires city and 24 districts, with an estimated population of 14 million, being the 10th largest megacity in the world and the $3^{\text {rd }}$ in Latin America. By its $200 \mathrm{~km}^{2}$, Buenos Aires is the largest city in Argentina, with a population of approximately 3 million people.

In the Delta Islands of the Paraná River, approximately 112 miles away from the city of Buenos Aires, pasture burning for grazing livestock is a fairly common practice. Between April $16^{\text {th }}$ and April $24^{\text {th }}$ 2008 , there was a series of wildfires that affected over 70,000 hectares. The extent of the fire, the drought, and the wind direction generated a thick cloud of smoke that caused the most severe episode of acute air pollution in the MABA ever recorded. The northern and northeas- tern areas of the province of Buenos Aires, including MABA, had been swathed in thick smoke (Figure $1 \mathrm{~A}, \mathrm{~B}$ ). It is estimated that the wildfires of the Delta of the Paraná River affected approximately 20 million people. The smoke was so dense in the city of Buenos Aires that on April $18^{\text {th }}$, the airports and highways were closed, and classes in all schools were suspended (Figure 1 B, C). The levels of carbon monoxide $(\mathrm{CO})$, nitrogen dioxide $\left(\mathrm{NO}_{2}\right)$, and particulate matter (PM) registered during the episode were the highest ever registered in the region of the River de la Plata.

Most of the previous studies on the impact of wildfires were conducted focusing on short-term outcomes related to hospital admittances or specific cohorts, particularly susceptible to respiratory distress, such as patients with chronic obstructive pulmonary disease or asthma or those who are directly exposed to the fires, such as firemen ${ }^{(1-3)}$.
Submitted for publication: September 8, 2014

Accepted for publication: January 26, 2015

Hospital de Oftalmología Pedro Lagleyze, Buenos Aires, Argentina.

Laboratorio de Investigaciones Oculares, Departamento de Patología, Facultad de Medicina, Universidad de Buenos Aires, Buenos Aires, Argentina.

3 Grupo de Monitoreo Ambiental, Comisión Nacional de Energía Atómica, Buenos Aires, Argentina.

${ }^{4}$ Laboratorio BioFundus, Buenos Aires, Argentina.
Funding: No specific financial support was available for this study.

Disclosure of potential conflicts of interest: None of the authors have any potential conflict of interest to disclose.

Corresponding author: Martín Berra. Laboratorio de Investigaciones Oculares. Departamento de Patología, Facultad de Medicina. Universidad de Buenos Aires - J.E Uriburu 950 - Postal Code 1114 Ciudad Autónoma de Buenos Aires, Buenos Aires - Argentina - E-mail: martinberra81@hotmail.com 

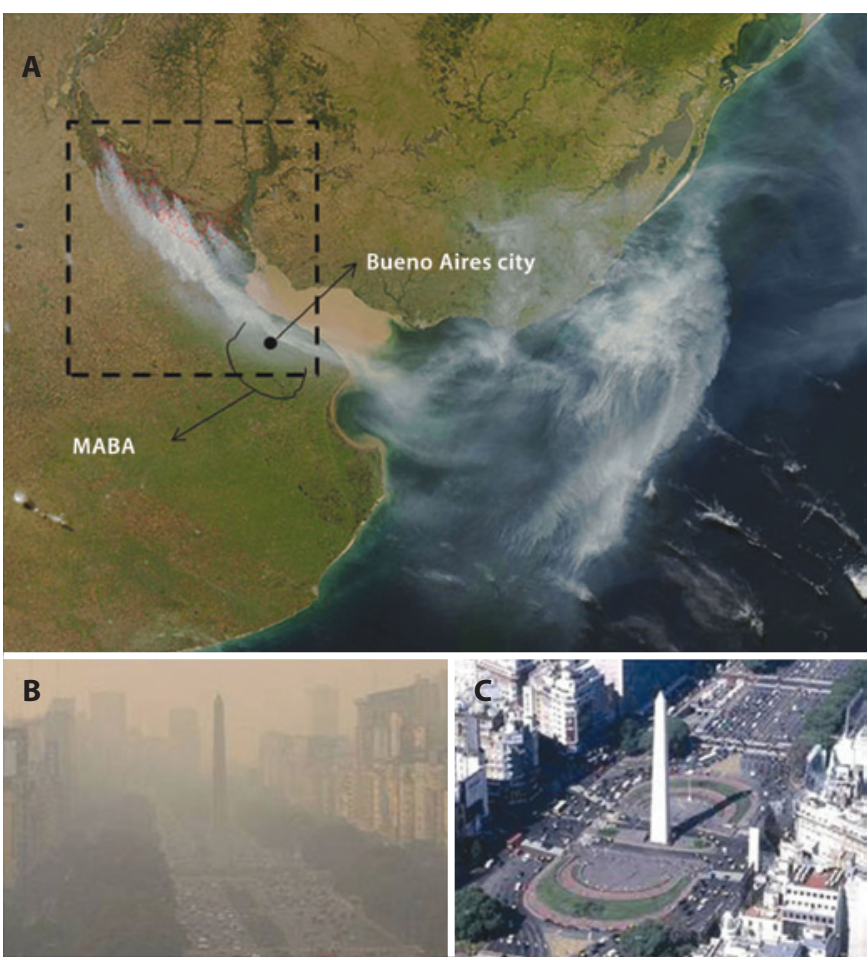

Figure 1. A) Satellite image (MODIS/Aqua) of the wildfires in the Delta of the Parana River on April $18^{\text {th }}$, 2008. Red boxes indicate wildfire areas. Scale: $1 \mathrm{px}=250 \mathrm{~m}$ (NASA. Fires and smoke over Argentina, seen from MODIS on the Aqua satellite at 2008/18/04 at 17:50 UTC. Scale: 1 px=250 m) http://rapidfire.sci.gsfc.nasa.gov/gallery/?20081090418/Argentina. A2008109.1750.250 m.jpg, 2008). B and C) Images of the same location in the city of Buenos Aires at two different moments: (B) April $18^{\text {th }}, 2008$, during the wildfires in the Delta of the Paraná River (http://nidodecaranchos.blogspot.com/2008 0401 archive. html). (C) May 20th, 2008 (http://cliobuenosaires.blogspot.com/2010/05/el-obelisco-unsimbolo-que-define.html).

The ocular surface is daily in contact with air, and epidemiological studies have indicated increasing incidence of dry eye disease (DED) worldwide ${ }^{(4-5)}$. This common ocular condition has multiple causes that are not entirely understood. The emerging awareness that environmental factors can contribute to DED is supported by recent studies ${ }^{(6-8)}$. Moreover, impact of the environment on the pathophysiology of DED has been studied and confirmed in animal models of DED ${ }^{(8-11)}$.

There are few studies that show the ocular impact of wildfires ${ }^{(12-13)}$ The wildfire episode in the northern area of the province of Buenos Aires was a unique opportunity to study the ocular impact of the exposure to the smoke produced by pasture burning on patients and healthy volunteers in a megacity.

\section{METHODS}

\section{Population OF STUDY}

The study population consisted of two groups, each with two subgroups (Table 1).

Group 1 (G1) comprised 35 patients who visited the Emergency Unit of Hospital Oftalmologico Pedro Lagleyze on April $19^{\text {th }}$ due to ocular complaints; Hospital Oftalmologico Pedro Lagleyze is the largest Ophthalmology Hospital in Argentina and located in the study area.

Group 2 (G2) included 51 healthy volunteers who accompanied the patients to the hospital on April $19^{\text {th }}$. Both groups were evaluated on a second appointment on May $22^{\text {nd }}$, when the air pollutant levels had recovered to normal values in the city of Buenos Aires (Table 1).

We included $35 / 67$ patients and 51/72 healthy volunteers because only 35 patients and 51 healthy volunteers visited the hospital on both April $19^{\text {th }}$ and May $22^{\text {nd }}$.
Table 1. Study population

\begin{tabular}{ccccc}
\hline Group & Subgroup & Subjects & N & $\begin{array}{c}\text { Time of examination } \\
\text { relative to the acute episode }\end{array}$ \\
\hline G1 & G1A & Patients & 35 & During (19 $9^{\text {th }}$ April) \\
& G1B & The same as G1A & 35 & After (22 ${ }^{\text {nd }}$ May) \\
G2 & G2A & Healthy volunteers & 51 & During (19 $9^{\text {th }}$ April) \\
& G2B & The same as G2A & 51 & After (22 ${ }^{\text {nd }}$ May) \\
\hline
\end{tabular}

To be included in G1 and G2, subjects had to give their informed consent before being enrolled in the study, had to be between 18 and 65 years old, and had to have lived and worked in MABA between March and May 2008, far from areas close to stationary sources of significant emissions, such as factories. The exclusion criteria for G2 included having a previous history of ocular surface disease or using contact lenses or any systemic or topical ocular drugs.

This study was conducted in accordance with the Declaration of Helsinki and was approved by the Ethical Committee of the Hospital Oftalmologico Pedro Lagleyze, Buenos Aires, Argentina.

\section{OCULAR SYMPTOMS QUESTIONNAIRE}

All subjects answered a symptoms questionnaire composed by questions that assessed the presence of ocular burning, dryness, foreign body sensation, irritation, and itching. Subjects were asked to grade the intensity of the symptoms on a scale of 1 to 3 ( $1=$ minor, $2=$ mild, and $3=$ severe). We also investigated if any factor worsened the symptoms, such as the time of the day of exposure, staying in- or outdoors, if it was the first time they experienced the symptoms, and if they were using any eye drops to improve the ocular symptoms.

\section{Ophthalmologic examination}

The usual ocular surface tests available in the hospital and our standard of care in our institution were used to evaluate the subjects.

\section{Bulbar conjunctival hyperemia}

Bulbar conjunctival hyperemia was recorded using five levels of severity from grade 0 (normal) to grade 4 (severe) (14) with a slit lamp (SL-8Z; Topcon Corp., Tokyo, Japan). The inter-subject variation in grading was determined to be 1.0 scale units. Interpretation of grading levels was as follows: $0=$ Normal, $1=$ Trace, $2=$ Mild, $3=$ Moderate, and 4 = Severe

\section{Corneal fluorescein staining}

Fluorescein staining with cobalt blue light was used to assess the presence or absence of corneal keratitis. Corneal fluorescein staining was evaluated with fluorescein strips (Diagnóstico Ocular, Buenos Aires, Argentina), which were wetted with $0.9 \%$ sodium chloride and gently applied to the inferior fornix. The cornea was divided into five regions (central, superior, inferior, nasal, and temporal), and each region was graded by a scale, with values ranging from grade 0 (normal) to grade 4 (severe) $)^{(14)}$. Grades of each area were added to produce a final score.

\section{Conjunctival rose bengal vital staining}

Vital staining with rose bengal was performed by instilling one drop of 1\% rose bengal solution (Farmacia Magister, Buenos Aires, Argentina) into the inferior fornix. The staining pattern was evaluated and graded according to the Van Bijsterveld scoring system on a scale that ranges from 0 to 9 . Scores higher than 4 were considered abnormal ${ }^{(15)}$.

\section{Tear break-up time}

Tear break-up time (TBUT) was measured by instilling one drop of $1 \%$ fluorescein solution (Farmacia Magister, Buenos Aires, Argentina) into the inferior fornix. The subject was asked to blink several times 
and then stop, at which point TBUT was assessed by monitoring the time (in seconds) elapsing to the appearance of the initial black spot on the cornea under slit lamp examination with a cobalt blue filter ${ }^{(16)}$. Values of 10 seconds or below were considered abnormal|(17).

\section{Schirmer's I test}

Subjects were evaluated by Schirmer's I test without topical anesthesia. One graded sterile Schirmer strip (Opthalmos ${ }^{\text {TM }}$, Brazil) was placed in the lateral canthus of the inferior lid margin of both eyes, and the subjects were instructed to keep their eyes closed during the test. After 5 minutes, the length of wetting was measured in millimeters, and values of $10 \mathrm{~mm}$ or less were considered abnormal|(17).

\section{Tear lysozyme concentration}

Tears were collected by gently applying a 5-mm diameter filter paper disc in the inferior conjunctival cul-de-sac of both eyes for one minute with eyes closed. Samples were kept at $-20^{\circ} \mathrm{C}$ until processed. To determine tear lysozyme concentration, we used the Micrococcus lysodeikticus (ATCC 4698, M3770; Sigma-Aldrich, St. Louis, MO) agar diffusion assay ${ }^{(18)}$ in Mueller Hinton agar plates (Bio Merieux, Marcy I'Etoile, France). Each disc was placed in the plate with the M. Iysodeikticus $\left(2 \times 10^{6} \mathrm{CFU} / \mathrm{mL}\right)$ suspension gel, and the inhibition halo was measured after 24 hours. To calculate the lysozyme concentration, a standard curve was obtained using identical discs wetted with $10,000,1,000,100$, and $10 \mu \mathrm{g} / \mathrm{mL}$ of lysozyme (ATCC 4698, L6876; Sigma-Aldrich) diluted in phosphate-buffered saline (Invitrogen Corp., Carlsbad, CA). Values of $1000 \mu \mathrm{g} / \mathrm{mL}$ or below were considered abnormal| ${ }^{(19-20)}$.

\section{Impression cytology}

Semicircular filters, approximately $15 \mathrm{~mm}$ diameter, (Polyvinylidene Fluoride -PVDF-, 22- 4 m pore size; Millipore Corp., Bedford, MA, USA) were applied to the inferior tarsal and bulbar conjunctiva after instillation of one drop of topical anesthetic (tetracaine) in each eye, and any excess fluid was wiped away. The paper fragments were gently pressured with the blunt end of the forceps, and the fragments were peeled off and immediately immersed in tubes containing absolute ethanol. After fixation, specimens were rehydrated in $70 \%$ ethyl alcohol, then placed successively in periodic acid-Schiff reagent, sodium metabisulfite, Gill's hematoxylin, and Scott's tap water. Specimens were then rinsed with 95\% alcohol and absolute alcohol. Xylene was used to make the filter paper transparent. Slides were examined under a conventional light microscope, using 400x magnification. Morphometric analysis was performed using a point-counting technique, PAS positive areas were counted across 10 random microscopic high-power fields (HPF) on a 100-point, and 50 lines grid on a video system coupled to the microscope. The result for each subject was calculated as the average of the 10 HPF counts. A single investigator performed all the observations and was blinded to the origin of the samples ${ }^{(18)}$.

Ocular damage was based on the scale of Nelson, comprising degrees of severity. This scale is based on the density of goblet cells and appearance of epithelial cells (grade squamous metaplasia). Level 0 is considered normal; 1 , slightly altered; 2 , moderately altered; and 3, severely altered ${ }^{(21)}$

\section{Assessment of air pollutants during and after the acute episode}

Average $\mathrm{CO}$ and $\mathrm{NO}_{2}$ concentrations over cumulative periods of three minutes were measured. The calibration of the equipment was made with high quality certified synthetic air. Nondispersive infrared absorptiometry was used to measure $\mathrm{CO}$ with an HORIBA monitor, model APMA-360, using a gas standard of 12 ppm to fix the span scale calibration. The HORIBA monitor APNA-360 was used for measuring $\mathrm{NO}_{2}$ on the basis of the chemiluminescence method. The equipment was calibrated with a NO gas standard of 99.7 ppm diluted with a 1:1000 ratio by means of an HORIBA device, SGGU.514. These measures were performed before, during, and after the acute episode. Data from particulate matter (PM) were obtained from the ambient agency of the city of Buenos Aires.

\section{Statistical ANALYSIS}

Results are expressed as the mean \pm standard deviation. When a test was performed in both eyes, the mean of the two measurements was used in the statistical analysis. Statistical analysis was performed using the T-test for independent samples to compare data between groups and the T-test for paired samples to compare data within groups. Linear regression was used to analyze the association between symptom levels and tear break-up time values. All tests were performed with a significance level of 0.05 using SPSS Statistics 17.0. (Copyright ${ }^{\odot} 2007$ Sun Microsystems, Inc., 4150 Network Circle, Santa Clara, California 95054, USA).

\section{RESULTS}

\section{OCULAR SYMPTOMS QUESTIONNAIRE}

The individuals of group G1 were patients who went spontaneously to the Emergency Unit of Hospital Oftalmologico Pedro Lagleyze with ocular complaints on April 19 $9^{\text {th }}, 2008$. The 35 patients in G1 included 25 women and 10 men, with an average age of 42.5 \pm 10.1 years. A total of 31/35 patients had a history of ocular surface pathology: Eighteen suffered from dry eyes (seven had Sjögren's syndrome), 10 from allergic conjunctivitis, and three suffered from ocular pemphigoid. Four patients had no history of ocular surface pathology but were included in this group because their ocular surface complaints were of a severity sufficient to attend hospital. During the acute episode, all patients (G1A) experienced at least three of the symptoms evaluated (burning, dryness, foreign body sensation, itchiness, and irritation). Burning, foreign body sensation, and irritation were the most frequent and severe symptoms (100\%) referred during the acute episode. A total of $83 \%$ experienced the symptoms during the whole day; $66 \%$ reported worsening of the symptoms when outdoors; and only $11 \%$ experienced these symptoms for the first time. There was a significant difference in the frequency and severity of the symptoms when the patients were compared over time, i.e., during vs. after the acute episode (G1A vs. G1B, $p<0.01$; Figure 2).

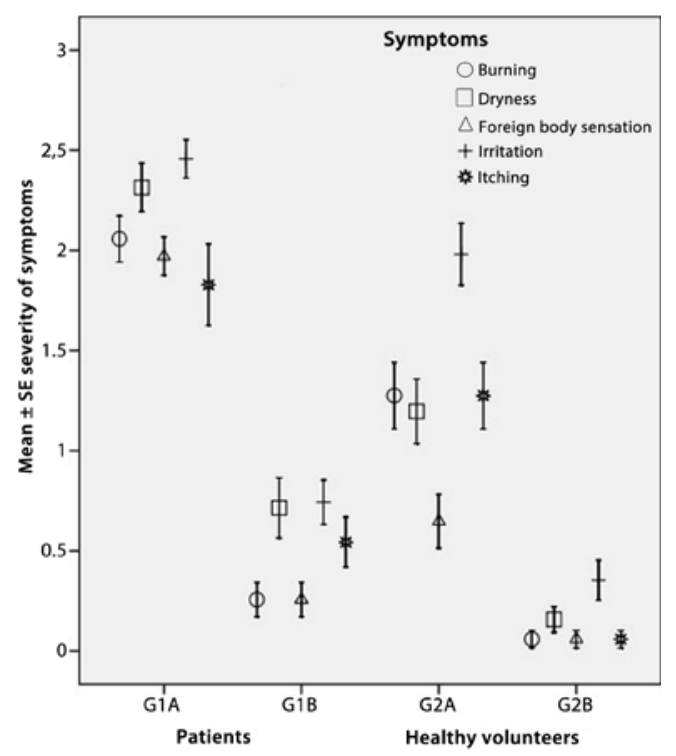

Figure 2. Severity of symptoms during and after the acute episode. The figure depicts the mean grade of the reported symptoms \pm the standard deviation of the mean for each of the two groups at two different time points [during $\left(19^{\text {th }}\right.$ of April) and after the episode $\left(22^{\text {nd }}\right.$ of May)]. $\mathrm{G} 1 \mathrm{~A}=$ patient data during the episode; $\mathrm{G} 1 \mathrm{~B}=$ patient data after the episode; $G 2 A$ = healthy volunteers data during the episode; $\mathrm{G} 2 \mathrm{~B}=$ healthy volunteers data after the episode. 
A total of 51 healthy volunteers were evaluated, including 23 women and 28 men, with an average age of $39.1 \pm 11.9$ years. During the acute episode, $79 \%$ of healthy volunteers (G2A) experienced at least three of the symptoms evaluated. The most frequent and severe symptom was ocular irritation (80\%). Most people reported sustaining ocular irritation during the whole day (55\%) or at the end of the day (41\%). In addition, $65 \%$ reported worsening of the symptoms when outdoors and $57 \%$ experienced these symptoms for the first time. There was a significant difference in the frequency and severity of the symptoms when the healthy volunteers were compared over time, i.e., during vs. after the acute episode (G2A vs. G2B, $p<0.01$; Figure 2).

\section{Ophthalmologic examination}

Table 2 shows the values obtained from G1A-B (N=35) and G2A-B $(N=51)$ for all tests performed.

The patients (G1) showed a statistically significant increase in bulbar conjunctival hyperemia (G1A vs. G1B, $p=0.0061$ ), corneal fluorescein staining (G1A vs. G1B, $p<0.0001$ ), and rose bengal vital staining (G1A vs. G1B, $p<0.0001$ ) during the acute episode.

The healthy volunteers ( $G 2$ ) only showed a statistically significant increase in bulbar conjunctival hyperemia (G2A vs. G2B, $p=0.0001$ ). No statistically significant differences were found in corneal fluorescein staining (G2A vs. G2B, p>0.05) or rose bengal vital staining (G2A vs. G2B, $p>0.05)$ during the acute episode.

No statistically significant differences within the groups were found when analyzing the values obtained by Schirmer's I test, tear lysozyme, and impression cytology.

The healthy volunteers showed statistically significant differences when compared with patients for the entire test performed during and after the acute episode (G1A vs. G2A and G1B vs. G2B, $p<0.05$ ).

Both patients (G1) and healthy volunteers (G2) showed a statistically significant $(p<0.0001)$ decrease in TBUT values during the acute episode. We also observed a negative correlation between severity of symptoms and TBUT values (Figure 3 ), significant $(p<0.05)$ for the symptoms dryness and irritation (Table 3).

\section{Pollutant levels}

During April $16^{\text {th }}$ to April $20^{\text {th }}$, the measured mean levels of CO, $\mathrm{NO}_{2}$, and $\mathrm{PM}$ concentrations were four times higher than the usual average levels for this time of the year. Figure 4 depicts the concentrations of these substances before, during, and after the episode. Hourly measured values of $\mathrm{CO}$ reached $17 \mathrm{ppm}$ on April $17^{\text {th }}$, which is 8.5 times as much as the average value (approximately 2 ppm) registered in the area. Moreover, the 8 hours average value was greater than the standard value recommended by the WHO Air Quality Guidelines (AQG) established by the World Health Organization ${ }^{(22)}$ in 29 opportunities. For $\mathrm{NO}_{2}$ and $\mathrm{PM}$, average levels are usually not exceeding $50 \%$ of the maximum levels recommended by the $\mathrm{WHO}$, but during the acute episode, the concentrations were twice as high as those recommended in the WHO guidelines ${ }^{(23-24)}$.

\section{DISCUSSION}

In this study, we assessed the impact of acute exposure to high levels of pollutants produced by pasture burning on the ocular surface of subjects living in an affected megacity.

Previous studies have demonstrated that ocular symptoms are a frequent finding in people exposed to the smoke generated by fires, including wildfires ${ }^{(12-13,24)}$.

During the acute episode, the patients who attended the hospital emergency room and the healthy volunteers experienced ocular symptoms, an increase in bulbar conjunctival hyperemia, and a reduction in TBUT values.

These results indicate that the patients showed more severe symptoms and a greater reduction in TBUT values. Meanwhile, Schirmer's I test, tear lysozyme, and impression cytology showed no differences.

Low TBUT values and high concentrations of air pollutants $\left(\mathrm{PM}_{10^{\prime}}\right.$ $\mathrm{NO}_{2}$, and $\mathrm{CO}$ ) measured during the acute episode indicated an influence of high concentrations of air pollutants on tear film stability; this result is similar to a previous study ${ }^{(25)}$.

The smoke generated by pasture burning is a complex mixture of potentially hazardous substances, including particles composed of polycyclic aromatic hydrocarbons, carbon monoxide, aldehydes, organic acids, organic compounds, nitrogen oxides, and sulfur ${ }^{(26)}$. These substances are directly in contact with the tear film and apparently cause tear film instability. The reported symptoms of burning, foreign body sensation, itching, and irritation are possibly caused by direct

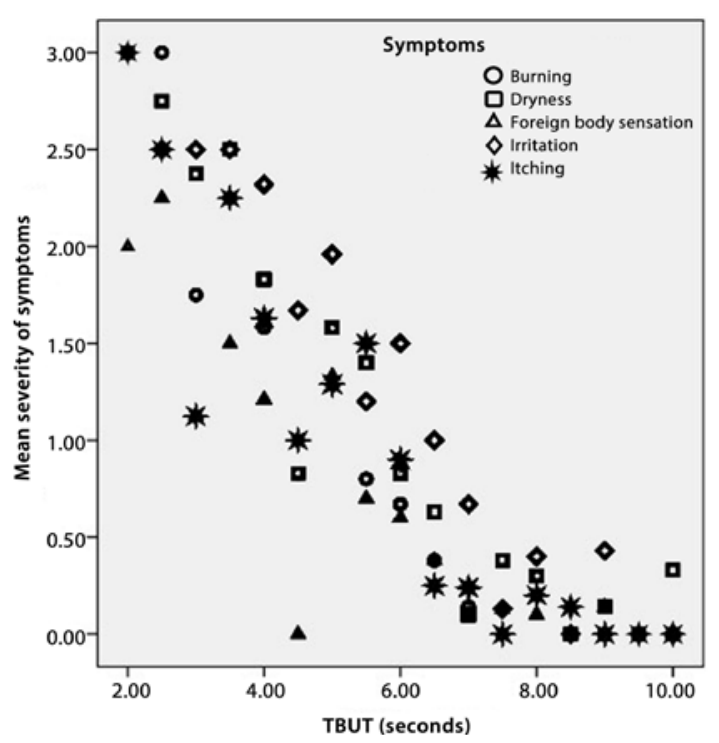

Figure 3. Correlation between severity of symptoms and tear break-up time (TBUT). There was a statistically significant correlation between the reported severity of ocularburning, dry eye, foreign body sensation, itching and irritation, and mean TBUT values. Values are expressed as means \pm 0.95 confidence intervals.

Table 2. Test results expressed as means \pm standard deviation obtained during and after the acute episode for each group

\begin{tabular}{|c|c|c|c|c|c|c|c|}
\hline Groups & $\begin{array}{c}\text { Bulbar conjuctival } \\
\text { hyperemia }\end{array}$ & $\begin{array}{c}\text { Cornea fluorescein } \\
\text { staining }\end{array}$ & $\begin{array}{l}\text { Rose bengal } \\
\text { vital staining }\end{array}$ & TBUT (seconds) & $\begin{array}{l}\text { Schirmer's I test } \\
\text { (mm/5 min) }\end{array}$ & $\begin{array}{c}\text { Tear lyzozyme } \\
\text { (ug/ml) }\end{array}$ & $\begin{array}{c}\text { Impression } \\
\text { cytology (10 HPF) }\end{array}$ \\
\hline G1A & $1.8 \pm 1.07 *$ & $3.7 \pm 1.2]_{*}$ & $6.4 \pm 2.17 *$ & $4.4 \pm 1.17 *$ & $11.3 \pm 9.5$ & $1533 \pm 987$ & $202 \pm 145$ \\
\hline G1B & $1.1 \pm 1.0$ & $1.9 \pm 0.7$ & $3.7 \pm 1.8$ & $6.2 \pm 1.3$ & $10.1 \pm 8.2$ & $1612 \pm 1072$ & $186 \pm 120$ \\
\hline G2A & $0.8 \pm 0.37 *$ & $0.7 \pm 0.3$ & $1.9 \pm 1.2$ & $4.9 \pm 1.27 *$ & $17.6 \pm 9.7$ & $2489 \pm 412$ & $298 \pm 132$ \\
\hline G2B & $0.3 \pm 0.1]$ & $0.6 \pm 0.2$ & $1.7 \pm 0.8$ & $7.8 \pm 1.2$ & $15.3 \pm 7.5$ & $2570 \pm 426$ & $315 \pm 151$ \\
\hline
\end{tabular}

${ }^{*} p<0.05$ among groups (G1A vs. G1B and G2A vs. G2B). All the differences between groups (G1A vs. G2A and G1B vs. G2B) were statistically significant. 
Table 3. Data obtained from linear regression analysis. Dependent variable $=$ TBUT

\begin{tabular}{lccccc}
\hline \multirow{2}{*}{$\begin{array}{l}\text { Constant } \\
\text { variables }\end{array}$} & \multicolumn{2}{c}{$\begin{array}{c}\text { Unstandardized } \\
\text { coefficients }\end{array}$} & $\begin{array}{c}\text { Standardized } \\
\text { coefficients }\end{array}$ & & \\
\cline { 2 - 4 } & $\mathbf{B}$ & Std. error & Beta & t & $\boldsymbol{p}$ \\
\hline Burning & -0.195 & 0.132 & -0.126 & -1.478 & 0.141 \\
Dryness & -0.388 & 0.128 & -0.261 & -3.029 & 0.003 \\
Foreign body & -0.108 & 0.102 & -0.064 & -1.061 & 0.290 \\
sensation & & & & & \\
Irritation & -0.524 & 0.113 & -0.370 & -4.622 & $<0.001$ \\
Itching & -0.072 & 0.096 & -0.052 & -0.745 & 0.457 \\
\hline
\end{tabular}

\section{A}
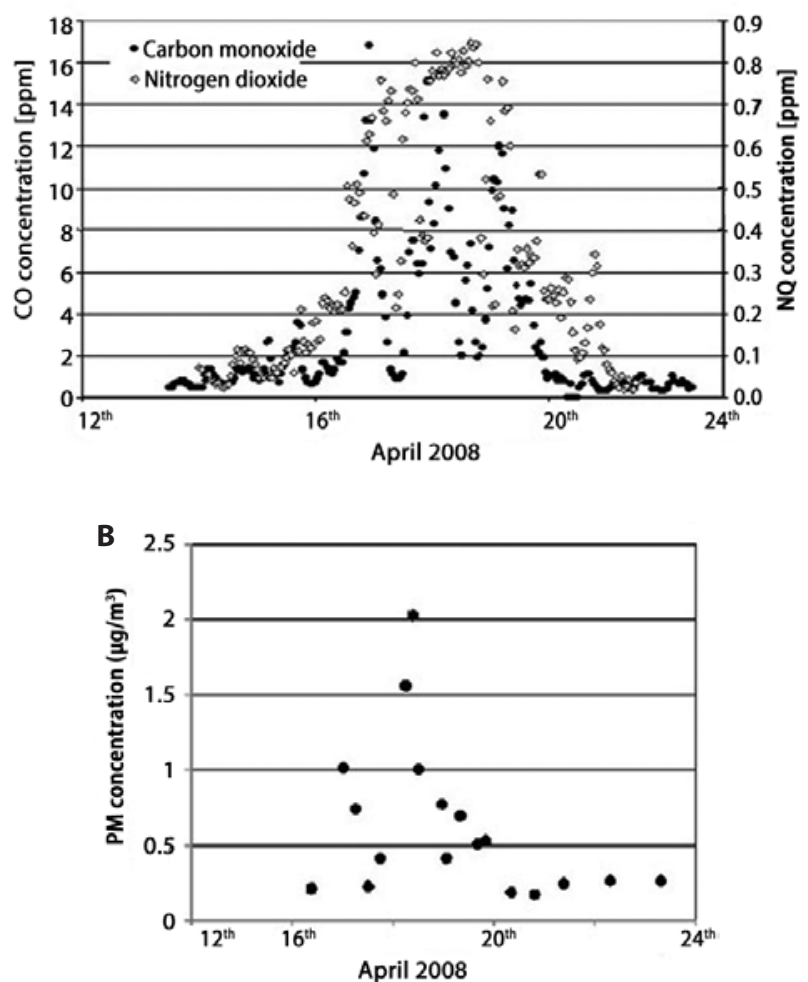

Figure 4. A) Carbon Monoxide ( $\mathrm{CO})$ and nitrogen dioxide $\left(\mathrm{NO}_{2}\right)$ hourly measured levels before, during, and after the acute episode. B) Levels of total particulate matter (PM) before, during, and after the acute episode. Data were obtained from the Environmental Protection Agency of Buenos Aires.

toxicity or as a consequence of ocular dryness caused by tear film instability.

\section{CONCLUSION}

In this study, we demonstrated that acute exposure to high levels of air pollution causes tear film instability without remodulation of the ocular surface. Furthermore, the perceptions of symptoms of normal subjects were not severe enough to trigger a visit to the emergency unit. In contrast, patients who suffered from dry eyes, allergic conjunctivitis, Sjögren's syndrome, and ocular pemphigoid experienced these symptoms with a higher degree of severity, triggering a visit to the emergency unit. This indicates that this last group of patients is more susceptible to developing and/or suffering from these ocular symptoms.

\section{REFERENCES}

1. Lipsett M, Waller K, Shusterman D, Thollaug S, Brunner W. The respiratory health impact of a large urban fire. Am J Public Health. 1994;84(3):434-8.

2. Mott JA, Meyer P, Mannino D, Redd SC, Smith EM, Gotway-Crawford C, et al. Wildland forest fire smoke: health effects and intervention evaluation, Hoopa, California, 1999. West J Med. 2002;176(3):157-62. Comment in: West J Med. 2002;176(3):162-3.

3. Vedal S, Dutton SJ. Wildfire air pollution and daily mortality in a large urban area. Environ Res. 2006;102(1):29-35. Comment in: Environ Res. 2008;106(3):423-4; discussion 425.

4. Moss SE, Klein R, Klein BE. Prevalence of and risk factors for dry eye syndrome. Arch Ophthalmol. 2000;118(9):1264-8.

5. Moss SE, Klein R, Klein BE. Incidence of dry eye in an older population. Arch Ophthalmol. 2004;122(3):369-73.

6. Iyer JV, Lee SY, Tong L. The dry eye disease activity log study. Scientific World J. 2012; 2012:589875.

7. Wolkoff $P$, Skov $P$, Franck C, Petersen LN. Eye irritation and environmental factors in the office environment-hypotheses, causes and a physiological model. Scand J Work Environ Health. 2003;29(6):411-30. Comment in: Scand J Work Environ Health. 2003; 29(6):407-9.

8. Alves M, Novaes P, Morraye Mde A, Reinach PS, Rocha EM. Is dry eye an environmenta disease? Arq Bras Oftalmol. 2014:77(3):193-200.

9. Barabino S, Dana MR. Animal models of dry eye: a critical assessment of opportunities and limitations. Invest Ophthalmol Vis Sci. 2004;45(6):1641-6.

10. Nakamura S, Shibuya M, Nakashima H, Hisamura R, Masuda N, Imagawa T, et al. Involvement of oxidative stress on corneal epithelial alterations in a blink-suppressed dry eye. Invest Ophthalmol Vis Sci. 2007;48(4):1552-8.

11. Stern ME, Schaumburg CS, Siemasko KF, Gao J, Wheeler LA, Grupe DA, et al. Autoantibodies contribute to the immunopathogenesis of experimental dry eye disease. Invest Ophthalmol Vis Sci. 2012:53(4):2062-75.

12. Kunzli N, Avol E, Wu J, Gauderman WJ, Rappaport E, Millstein J, et al. Health effects of the 2003 Southern California wildfires on children. Am J Respir Crit Care Med. 2006;174(11):1221-8. Comment in: Am J Respir Crit Care Med. 2007;175(6):629; author reply 629; Am J Respir Crit Care Med. 2006;174(11):1168-9.

13. Viswanathan S, Eria L, Diunugala N, Johnson J, McClean C. An analysis of effects of San Diego wildfire on ambient air quality. J Air Waste Manag Assoc. 2006;56(1):56-67.

14. Efron N. Grading scales for contact lens complications. Ophthalmic Physiol Opt. 1998 18(2):182-6.

15. Lemp MA. Report of the National Eye Institute/Industry workshop on Clinical Trials in Dry Eyes. CLAO J. 1995;21(4):221-32.

16. van Bijsterveld OP. Diagnostic tests in the Sicca syndrome. Arch Ophthalmol. 1969; 82(1):10-4.

17. The definition and classification of dry eye disease: report of the Definition and Classification Subcommittee of the International Dry Eye WorkShop (2007). Ocul Surf. 2007;5(2):75-92.

18. Novaes P, do Nascimento Saldiva PH, Kara-Jose N, Macchione M, Matsuda M, et al Ambient levels of air pollution induce goblet-cell hyperplasia in human conjunctival epithelium. Environ Health Perspect. 2007;115(12):1753-6.

19. Gonzalez-Garcia MJ, Gonzalez-Saiz A, de la Fuente B, Morilla-Grasa A, Mayo-Iscar A San-José J, et al. Exposure to a controlled adverse environment impairs the ocular surface of subjects with minimally symptomatic dry eye. Invest Ophthalmol Vis Sci. 2007:48(9):4026-32.

20. Jones LT. The lacrimal secretory system and its treatment. Am J Ophthalmol. 1966 62(1):47-60.

21. Nelson JD. Impression cytology. Cornea. 1988;7(1):71-81.

22. World Health Organization. Carbon Monoxide. 2nd ed. Geneva: WHO; 1999. (Environmental Health Criteria 213)

23. World health Organization. WHO Air quality guidelines for particulate matter, ozone nitrogen, dioxide and sulfur dioxide. Global update 2005. Summary of risk assessment [Internet]. Geneva:WHO; 2005. (WHO/SDE/PHE/OEH/06.02.) [cited 2008 Jul 27]. Available from: http://whqlibdoc.who.int/hq/2006/WHO_SDE_PHE_OEH_06.02_eng.pdf

24. Morgan O, Verlander NQ, Kennedy F, Moore M, Birch S, Kearney J, et al. Exposures and reported symptoms associated with occupational deployment to the Buncefield fuel depot fire, England 2005. Occup Environ Med. 2008;65(6):404-11.

25. Novaes P, Saldiva PH, Matsuda M, Macchione M, Rangel MP, Kara-Jose N, et al. The effects of chronic exposure to traffic derived air pollution on the ocular surface. Environ Res. 2010;110(4):372-4.

26. Zelikoff JT, Chen LC, Cohen MD, Schlesinger RB. The toxicology of inhaled woodsmoke J Toxicol Environ Health B Crit Rev. 2002;5(3):269-82. 